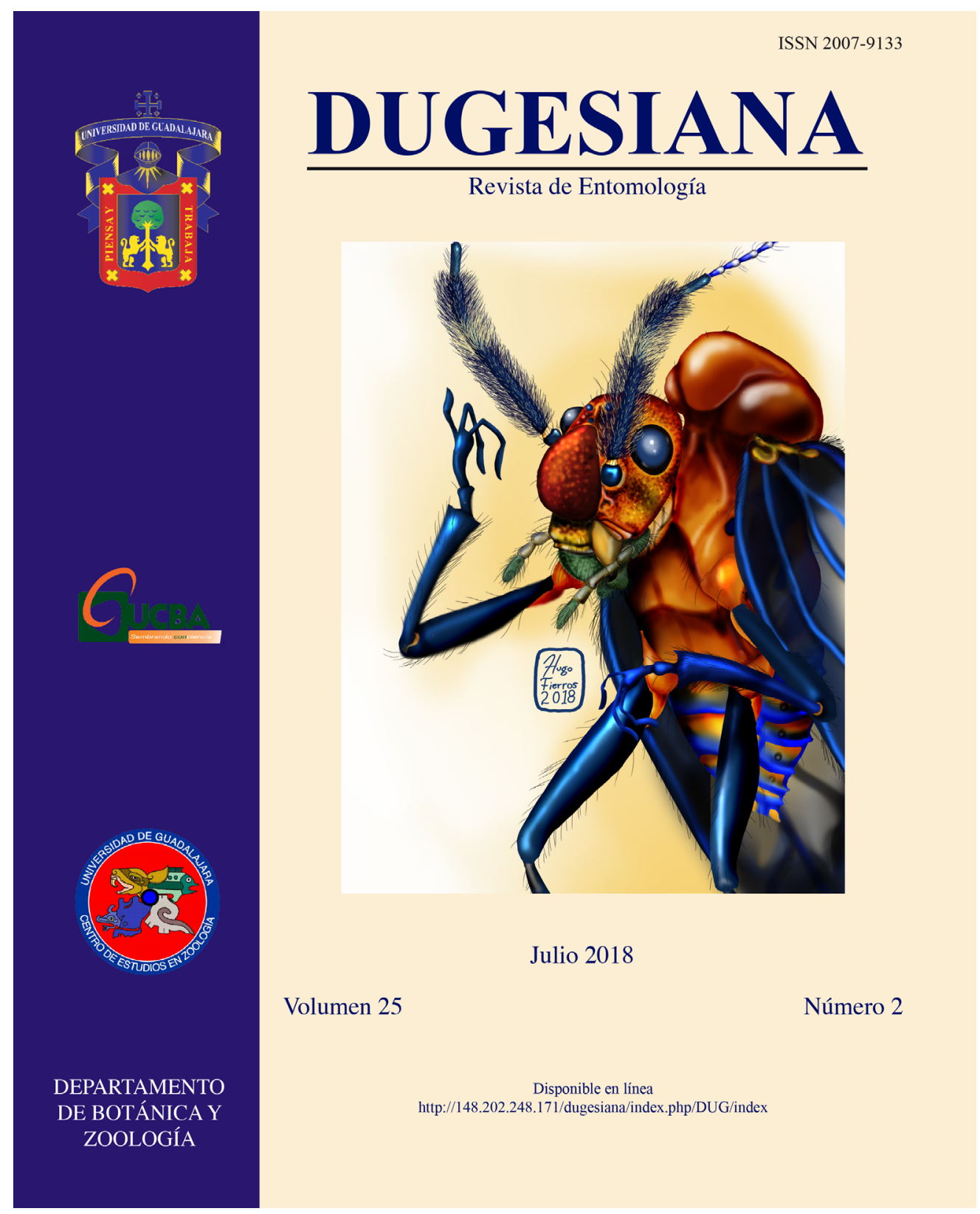

Dugesiana, Año 25, No. 2, julio 2018-diciembre 2018 (segundo semestre de 2018), es una publicación semestral, editada por la Universidad de Guadalajara, a través del Centro de Estudios en Zoología, por el Centro Universitario de Ciencias Biológicas y Agropecuarias. Camino Ramón Padilla Sánchez \# 2100, Nextipac, Zapopan, Jalisco, Tel. 37771150 ext. 33218, http://148.202.248.171/dugesiana/index.php/DUG/index, glenusmx@gmail.com. Editor responsable: José Luis Navarrete Heredia. Reserva de Derechos al Uso Exclusivo 04-2009-062310115100203, ISSN: 2007-9133, otorgados por el Instituto Nacional del Derecho de Autor. Responsable de la última actualización de este número: José Luis Navarrete Heredia, Editor y Ana Laura González-Hernández, Asistente Editorial. Fecha de la última modificación 25 de julio 2018, con un tiraje de un ejemplar.

Las opiniones expresadas por los autores no necesariamente reflejan la postura del editor de la publicación.

Queda estrictamente prohibida la reproducción total o parcial de los contenidos e imágenes de la publicación sin previa autorización de la Universidad de Guadalajara. 


\title{
A new species of Iralunelus Stys, 1974 (Hemiptera: Heteroptera: Aradidae) from Colombia
}

\author{
Una nueva especie de Iralunelus Stys, 1974 (Hemiptera: Heteroptera: Aradidae) de Colombia
}

\author{
Eugenia Fernanda Contreras ${ }^{1 *}$, Lilia Estela Neder $^{1}$ and María del Carmen Coscarón ${ }^{2}$ \\ ${ }^{1}$ Instituto de Biología de la Altura, Universidad Nacional de Jujuy. Av Bolivia 1661. 4600. San Salvador de Jujuy, \\ Jujuy, Argentina. ${ }^{2}$ Facultad de Ciencias Naturales y Museo, Universidad Nacional de la Plata. Paseo del Bosque \\ S/N.1900. La Plata, Buenos Aires, Argentina, e-mail: eugecon09@gmail.com*
}

\section{RESUMEN}

Una especie nueva del género Iralunelus Ŝtys, 1974: I. zipaquirensis sp. n. Contreras, Neder y Coscarón de Zipaquirá, Colombia es descripta e ilustrada. Esta especie es cercana a I. sahlbergi (Bergroth, 1886) y a I. simulans (Walker, 1873) por la presencia de una callosidad oval en el escutelo y por los ángulos anterolaterales del pronoto redondeados; pero puede distinguirse de estas por los siguientes caracteres: escutelo con una callosidad redondeada grande sobre la mitad anterior; conexivo delgado; paratergitos VIII del macho rectangulares con el ápice truncado, y ubicados oblicuamente a la longitud del pigóforo. Se ofrecen ilustraciones de la genitalia de la nueva especie.

Palabras clave: Aneurinae, Colombia, taxonomía, Zipaquirá.

\section{ABSTRACT}

A new species of genus Iralunelus Stys, 1974: I. zipaquirensis Contreras, Neder and Coscarón sp. n. from Zipaquirá, Colombia, is described and illustrated. This new species is close to I. sahlbergi (Bergroth, 1886) and I. simulans (Walker, 1873) for the presence of a callus on the scutellum and the anterolateral angles of pronotum rounded, but can be distinguished by the following characters: scutellum with a large rounded callus on anterior half; connexiva narrow; male paratergites VIII rectangular with truncated apex, reaching half the length of pygophore. Figures of the genitalia of the new species are provided.

Key words: Aneurinae, Colombia, taxonomy, Zipaquirá.

The genus Iralunelus Stys belongs to the Aneurinae subfamily and is distributed in the Neotropical, Neartic and Paleartic regions. Initially it was proposed as a subgenus of Aneurus by Stys (1974) base on the presence of a split abdominal segment VII. Kormilev and Froeschner (1987) promoted it to full generic rank, and included 20 species of which 18 are distributed in the Neotropical Region: Iralunelus aibonitensis (Kormilev, 1968b), I. bergi (Kormilev, 1980), I. bispinosus (Kormilev, 1960a), I. bolivianus (Kormilev, 1960b), I. carioca (Kormilev, 1968a), I. costariquensis (Kormilev, 1982), I. flavomaculatus (Distant, 1893), I. fritzi (Kormilev, 1960b), I. leptocerus (Hussey, 1957), I. longicornis (Kormilev, 1982), I. marginalis (Walker, 1873), I. monrosi (Kormilev, 1980), I. plaumanni (Kormilev, 1965), I. sahlbergi (Bergroth, 1886), I. simulans (Walker, 1873), I. subdipterus (Burmeister, 1835), I. tenuis (Champion, 1898), I. wygodzinskyi (Picchi, 1977), one in the Nearctic Region Iralunelus politus (Say, 1832) and one in the Palearctic Region: I. gallicus (Ŝtys, 1974). Subsequently, the records by Coscarón and Contreras (2012, 2015) extended the distribution of I. politus into the Neotropics. The present work describes a new species of Iralunelus from Colombia.

\section{MATERIALS AND METHODS}

The description is based on three males and two females provided by the American Museum of Natural History, New
York, United States of America (AMNH). Measurements are given in millimeters and morphological characters were analyzed using optical instruments EZ4 Leica and camera Sony DSC-P200.

\author{
RESULTS \\ TAXONOMY \\ Aradidae Brullé, 1836
}

Aneurinae Douglas and Scott, 1865 Iralunelus Stys, 1974

Iralunelus zipaquirensis sp. nov.

Figures $1 \mathrm{~A}-\mathrm{C}$

http://zoobank.org/6EF591BF-17BB-436D-907BEB4EB88698B4

Diagnosis. I. zipaquirensis presents the following characters: scutellum with a large, rounded callus on the anterior half (Fig. 1A); connexiva narrow (Fig. 1A); male paratergites VIII rectangular with truncate apex, half the length of pygophore (Fig. 1C). Parameres shaped, dentate at middle, with long setae in the distal portion.

Description. Holotype male (Fig. 1A) Small. Total length $4.70 \mathrm{~mm}$, body oval, surface rugose; head, pronotum, scutellum and basal portion of hemelytra dark brown; labium, coxa, connexiva and abdominals sterna reddish brown.

Head. Almost as long as wide across eyes (1: 1.05). 
Clypeus conical, exceeding the antennal segment I; genae poorly developed and barely visible dorsally. Antennae about twice the width of the head (1: 1.98), antenniferous lobes subrectangular anterolaterallty rounded; antennal segment I suboval, II basally narrowed, III cylindrical of the same length as II, IV fusiform, distal portion of the III and IV beset with hairs. Relative length of segments I:II:III:IV= 1:1.53:1.53:3.11, eyes moderately large, protruding; postocular tubercles (pt) short, not reaching the outer margin of the eyes; vertex transversely striate with two ovate callosities; labium reaching the posterior margin of eyes.

Pronotum. Length less than half of maximum width (1: 2.14); anterior margin concave at middle, anterolateral angles rounded, not extending beyond the collar, neither exceeding the neck; lateral margins of anterior lobe converging anteriorly, subsequently divergingand with deep lateral cleft; fore disk with four callosities; hind disk granulate anteriorly, and with an elongated depression in the posterior half, followed by transverse striations posteriorly; posterior margin slightly curved in the middle.

Scutellum. Semicircular, shorter than basal width (1: 1.61); fore disc depressed with a large spot (ss) that exceeds half lenght of scutellum; hind disc with semicircular striations.

Abdomen. Ovate, longer than wide across segment IV (1: 0.69); connexiva narrow (c) with smooth lateral margins; postero-exterior angles not protruding; tergum VII with two triangular paratergites (pa VII); spiracles II and VII located laterally and visible from above; those of III -VI more ventrally, far from outer margin of connexivum; VIII terminal. Hemelytra distally surpassing half of tergum VII, corium longer than half lenght of scutellum (1: 0.6); membrane finelly wrinkled.

Legs. Femora and tibiae striated and pilose.

Genital structures. (Fig. 1C): pygophore piriform and as long as wide (1: 1); paratergites VIII (pa VIII) rectangular with truncate apex, half the lenght of pygophore. Parameres blade shaped, dentate at middle, apically with long setae (sp).

Female. (Fig. 1B): paratergites of segment VIII subtriangular, not surpassing the segment.

Measurements. Holotype male. Total length: $4.70 \mathrm{~mm}$. Head length: $0.62 \mathrm{~mm}$., width: $0.65 \mathrm{~mm}$. Antennal segments length I: 0.17 , II: 0.26 , III: 0.26 , IV: 0.53 . Pronotum length: $0.69 \mathrm{~mm}$., width: $1.48 \mathrm{~mm}$. Scutellum length: 0.65 mm., width: $1.05 \mathrm{~mm}$. Abdomen length: $2.69 \mathrm{~mm}$., width $1.86 \mathrm{~mm}$. Pygophore length: $0.40 \mathrm{~mm}$., width: $0.40 \mathrm{~mm}$. Allotype female. Total length: $5.18 \mathrm{~mm}$. Head length: 0.67 mm., width: $0.73 \mathrm{~mm}$. Antennal segments length I: 0.21, II: 0.26, III: 0.28 , IV: 0.60 . Pronotum length: $0.74 \mathrm{~mm}$., width: $1.55 \mathrm{~mm}$. Scutellum length: $0.63 \mathrm{~mm}$., width: $1.12 \mathrm{~mm}$. Abdomen length: $3.10 \mathrm{~mm}$., width $2.10 \mathrm{~mm}$.

Paratypes. Total length: $+9,1 ; 04,45-4,92-5,10$. Head

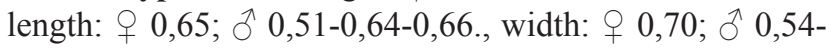
$0,66-0,67$. Antennal segments length I: + 0,19 , त 0,17 -

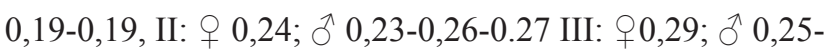
$0,25-0,26$; IV: $\odot 0,62 ; 0,0,51-0,56-0,57$. Pronotum length: q 0,$71 ;$ ô $0,64-0,67-0,69$., width: $+1,51 ;$ o $1,46-1,49-1,51$. Scutelum length: $q 0,60$; ${ }^{\wedge} 0,62-0,69-0,70$, width: 우 1,17; ô 1,01-1,06-1,08. Abdomen length: ㅇ 3,10; $\widehat{o}$ 2,55-2,863,12, width: of 2,07; ô1,89-1,98-2,03. Pygophore length: 0,39-0,43-0,44., width: 0,40-0,43-0,44.

Material examined: Holotype. $\hat{\partial}$, Colombia, Cundinamarca, Road Zipaquirá to Pacho, $3400 \mathrm{~m}, 5^{\circ}$ $03^{\prime} 51,55^{\prime \prime} \mathrm{N}, 74^{\circ} 02^{\prime} 22,66^{\prime \prime} \mathrm{W}, 22-\mathrm{VII}, 1967, \mathrm{P} \&$ B. Wygodzinsky, (AMNH). Allotype. ㅇ, Colombia, Cundinamarca, Road Zipaquirá to Pacho, $3400 \mathrm{~m}, 5^{\circ}$ $03^{\prime} 51,55^{\prime \prime} \mathrm{N}, 74^{\circ} 02^{\prime} 22,66^{\prime \prime} \mathrm{W}, 22-\mathrm{VII}, 1967$, P \& B. Wygodzinsky (AMNH).

Paratypes. $1 \uparrow$ and $3 \hat{\partial}$, same data (AMNH).

Etymology. The specific epithet refers to the type locality (Zipaquirá).

Distribución. Cundinamarca, Colombia.

Natural history. Unknown, except that the habitat in which this species was collected is located at an altitude of $3400 \mathrm{~m}$.

Comentary. The most similar species to I. zipaquirensis are I. sahlbergi (Bergroth, 1886) and I. simulans (Walker, 1873) for the presence of a callus on the scutellum and the rounded anterolateral angles of pronotum. However, $I$. sahlbergi differs by the poorly marked pronotal callosities and dark body coloration. In Iralunelus sahlbergi and $I$. simulans the pygophore is longer than wide and the apex of paratergites VIII are rounded.

\section{ACKNOWLEDGEMENTS}

We thank Mario Linares for taking the pictures. We want to express our gratitude to Randall Schuh and Ruth Salas (AMNH) for the loan of the specimens studied. This work was supported by the Consejo Nacional de Investigaciones Científicas y Técnicas (CONICET).

\section{LITERATURE CITED}

Bergroth, E. 1886. Zur Kenntniss der Aradiden. Verhandlungen der Zoologisch-Botanischen Gesellschaft in Wien, 36: 53-60.

Brullé, A. 1836. Histoire naturelle des insects, traitant de leur organization et de leurs moeurs en general, et comprenant leur classification et la description des espèces. Pillot, Paris.

Burmeister H.C.C. 1835-1839. Handbuch der Entomologie. 2 vol. T. Enslin, Berlin.

Champion, G.C. 1898. Insecta. Rhynchota. (Hemiptera Heteroptera). (vol. 2, pp.33-192). In: Godwin F. and O. Salvin (Eds.). Biologia Centrali-Americana. Taylor and Francis, London.

Coscarón, M.C. \& E.F. Contreras. 2012. Catalog of Aradidae (Hemiptera:Heteoptera) for the Neotropical Region. Zootaxa, (3466): 1-103.

Coscarón, M.C. and E.F. Contreras. 2015. Flat Bugs (Aradidae) (pp 423 - 458). In: Pannizi R.A. and J. 
Grazia (Eds.) True Bugs (Heteroptera) of the Neotropics. Springer publishing, London.

Distant, W.L. 1893. Descriptions of New Genera and New Species of Neotropical Rhynchota. Transactions of the Royal Entomological Society of London, 41 (1): 83-96.

Douglas, J.W. and J. Scott. 1865. The British Hemiptera. Volume I, Hemiptera-Heteroptera. Ray Society, London.

Hussey, R.F. 1957. Two Changes in name of Hemiptera (Aneuridae and Miridae). Florida Entomology, 40 (2): 80 .

Kormilev, N.A. 1960a. Notas sobre Aradidae Neotropicales VIII (Hemiptera). Anales de la Sociedad Científica Argentina, 169(5-6): 83-94.

Kormilev, N.A. 1960b. Notes on Neotropical Aradidae XI (Hemiptera). Journal of the New York Entomological Society, 68 (4): 208-220.

Kormilev, N.A. 1965. Notes on Neotropical Aradidae XV (Hemiptera - Heteroptera). Opuscula Zoologica, (84): $1-7$.

Kormilev N.A. 1968a. Notes on Neotropical Aradidae XVIII (Hemiptera-Heteroptera). Papeis Avulsos de Zoologia, 22(6): 47-56.

Kormilev N.A. 1968b. North and Central American species of Aneurus Curtis (Hemiptera: Aradidae). Proceedings of the United States National Museum, 125 (3657): $1-12$.

Kormilev N.A. 1980. Sobre especies Argentinas del género Aneurus, Curtis, 1825. Acta Zoológica Lilloana, 36 (1): 53-56.

Kormilev N.A. 1982. Records and Descriptions of Central American Aradidae (Hemiptera). The Wasmann Journal of Biology, 40 (1-2): 26-44.

Kormilev N.A. and R.C. Froeschner 1987. Flat Bugs of the World. A Synonymic List (Heteroptera: Aradidae). Entomography, 5: 1-246.

Picchi V.D. 1977. A Systematic Review of the Genus Aneurus Curtis of North and Middle America and the West Indies (Hemiptera: Aradidae). Quaestiones Entomologicae, 13 (3): 155-308.

Say T. 1832. Descriptions of new species of Heteropterous Hemiptera of North America. New Harmony, Indiana.

Stys P. 1974. Morphological and taxonomic notes on the Aneurinae, with description of Aneurus (Iralunelus subgen. $n$.) gallicus $\mathrm{sp}$. n. from France, and a world list of species (Heteroptera, Aradidae). Acta Entomologica Bohemoslovaca, 71 (2): 86-104.

Walker F. 1873. Corticolae. Catalogue of the Specimens of Hemiptera Heteroptera in the Collection of the British Museum. Part VII: 6-44.

Recibido:7 de noviembre 2017

Aceptado: 1 de febrero 2018

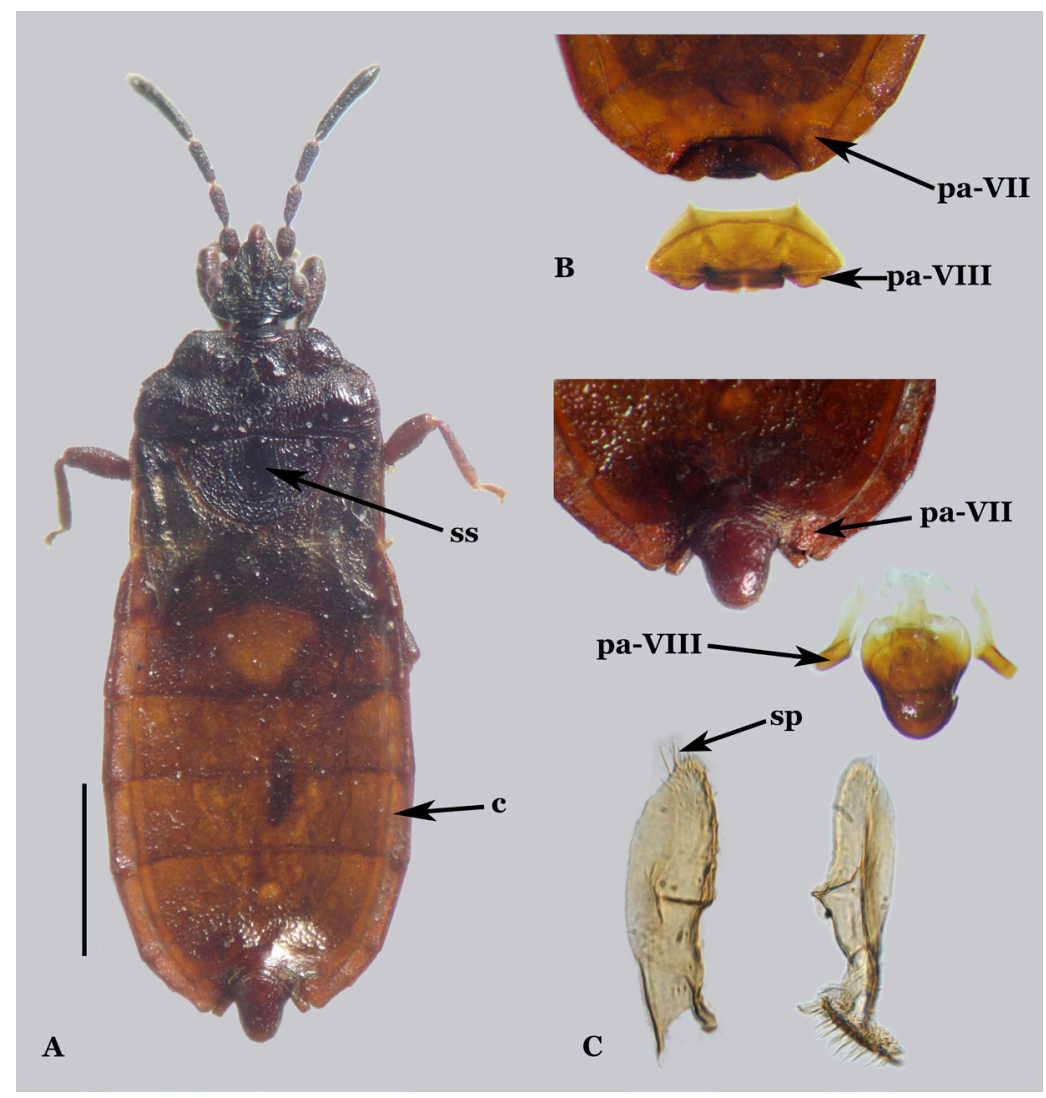

Figure 1 (A-C). Iralunelus zipaquirensis sp. n. (A) Male holotype, spot on scutellum (ss), connexivum (c), dorsal view; (B) Female allotype, terminal segments VI-IX, paratergites of segment VII (pa-VII), paratergites of segment VIII (pa-VIII), dorsal view; (C) Male holotype, terminal segments VI-VIII, paratergites of segment VII (pa-VII), paratergites of segment VIII (pa-VIII), setae of paramere (sp), dorsal view. 